\title{
Developing Students' Mathematical Critical Thinking Skills Using Open-Ended Questions and Activities Based on Student Learning Preferences
}

\author{
Natthanon Monrat $\mathbb{D}^{\text {D, }}$, Mingkhuan Phaksunchai $(\mathbb{D}$, and Ratchanikorn Chonchaiya \\ Faculty of Science, King Mongkut's University of Technology Thonburi, 126 Pracha Uthit Rd., Bang Mod, Thung Khru, \\ Bangkok 10140, Thailand
}

Correspondence should be addressed to Mingkhuan Phaksunchai; mingkhuan.pha@mail.kmutt.ac.th

Received 28 October 2021; Accepted 28 December 2021; Published 27 January 2022

Academic Editor: Enrique Palou

Copyright (c) 2022 Natthanon Monrat et al. This is an open access article distributed under the Creative Commons Attribution License, which permits unrestricted use, distribution, and reproduction in any medium, provided the original work is properly cited.

\begin{abstract}
This study has two parts: phase I designed activities to support all students' learning preferences, and phase II used open-ended questions and activities based on these preferences to develop students' mathematical critical thinking skills in polynomials at all performance levels (i.e., high-achieving, fair-achieving, and low-achieving students). This research used an embedded mixedmethod design. The subjects selected were 28 out of 98 seventh graders at a boys' junior high school in Bangkok, Thailand, who were chosen by cluster random sampling technique. The instruments, which were validated by five experts, included a questionnaire, lesson plans, exit tickets, interview protocols, and tests of critical thinking skills in polynomials. The content validity was assessed via expert judgment, and reliability was assessed by item analysis. The quality and effectiveness of the instruments were acceptable. The research results showed the following: (1) most students at all performance levels prefer activities in which they can learn from participating in classroom activities, such as games, activities with real-life applications, and activities involving listening instead of reading and writing, and (2) critical thinking skills in high-achieving and fair-achieving students were at the fair level, while those of low-achieving students were poor. Analysis was the highest critical thinking subskill among highachieving and low-achieving students, while interpretation was the highest subskill in among fair-achieving students. Open-ended questions and activities based on students' preferences appear to be practical for developing critical thinking skills among students of all achievement levels.
\end{abstract}

\section{Introduction}

The Thai government has set critical thinking as one of the key 21st-century skills in its National Education Plan [1] because they are essential for students' future success [2-5]. Critical thinking skills are necessary in the workplace [6-8] and can assist students in solving problems, making decisions, and managing their lives $[9,10]$. According to Facione et al., critical thinking skills involve reasonable reflective thinking through the process of evaluation or judgment for interpretation, analysis, and inference using deductive and inductive reasoning to come to a decision about the problems considered [3, 11-14]. Students' critical thinking skills should be practiced in secondary school $[15,16]$.
According to international tests (PISA and TIMSS), Thai students have low critical thinking skills in mathematics. PISA (2018) reported that the students' average scores in Thailand are less than the OECD average scores, which means that students cannot model complex situations mathematically and select, compare, and evaluate appropriate problem-solving strategies for dealing with those situations [17]. TIMSS (2015) reported that secondary students' skills in mathematical concepts-including numbers, algebra, geometry, data analysis, and probability-are low. Secondary students also have some misconceptions about polynomials and make mistakes when adding and subtracting polynomials, representing signs incorrectly in complex problems. Such findings were also revealed in 
interviews with mathematics teachers who taught seventh graders for more than five years. Students also have some misconceptions in addition, subtraction, multiplication, and division [18-20], and it has been acknowledged that students need to develop critical thinking skills in mathematics [21].

Based on the country's primary core curriculum, Thai students must spend at least 6 hours a day in the classroom with teacher-centered learning, and students can be regarded as passive learners who listen and copy what has been written and said by the teacher [5, 22, 23]. Students might not learn efficiently because they have different learning styles [24-26], including the VARK sensory learning preferences (visual, aural, read/write, and kinesthetic) [26]. Several studies related to learning preferences have found that designed activities to support all student learning preferences can promote motivation and perception [27-30], and learning preferences could support students' achievement [30, 31]. High-achieving and low-achieving students have also been shown to have different learning preferences [32], although students can acclimate their learning preferences to new situations and find suitable ways to learn that content; the teacher therefore needs to prepare activities and tools that cover a diversity of learning preferences [33].

Mathematics is one of the subjects that is useful for developing students' critical thinking skills [34-38] because it involves reasoning, making decisions, and solving problems. Mathematical critical thinking skills involve the process of thinking and integrating knowledge of mathematics to solve mathematical problems using mathematical reasoning and problem-solving strategies [35, 39]. It has been suggested that instructional strategies develop critical thinking skills by allowing students to solve problems, using open-ended questions and providing various learning activities to engage students in solving those problems $[38,40]$. Open-ended questions create meaningful learning opportunities by prompting children to reason and reflect while encouraging their use of language [41, 42]. Such questioning allows students to think actively and improve their problemsolving skills [43] because questions beginning with what, why, or how develop the abilities to interpret, analyze, evaluate, and make decisions and explain information based on reasoning [3, 34, 44-46]. Open-ended questions are thus practical for leading students to think critically based on their own knowledge and reasoning.

According to Firdaus et al., allowing students to solve open-ended questions related to daily life or their own experiences is an effective way to develop mathematical critical thinking skills and achievement among secondary students [35, 47]. Winarso and Hardyanti found that using open-ended questions can develop critical thinking skills in mathematics in low-achieving students [48]. The questions can also stimulate student participation $[49,50]$ and can elicit feedback on students' understanding and thinking [36, 51-53]. The developed critical thinking skills also affect student's performance differently, and highachieving students can develop critical thinking skills in mathematics more easily than low-achieving students [54-57].
There are different components in measuring critical thinking skills in mathematics among high school students. Following Watson and Glaser, Aiyub et al. developed a fivepart model for mathematical critical thinking problems: inference making, recognition of assumptions, deduction, interpretation, and evaluation of arguments [58]. Basri et al. followed Facione (2020) and identified six subskills: interpretation, analysis, evaluation, inference, explanation, and selfregulation [51]. Although Facione found six subskills for critical thinking, some studies have only considered four or five subskills. Sari and Caswita (2019) measured only interpretation, analysis, evaluation, and inference [59], while Seventika et al. developed mathematical critical thinking skills based on Facione, and Angelo's assessment considered five indicators: interpreting problems, analyzing the problem, applying the gained solution, evaluating the gained solution, and concluding the results attached with supporting evidence [56].

According to the observation, interviews with teachers, and review of measures for critical thinking skills in high school, the students in the studied school need to improve their critical thinking skills in interpretation, analysis, evaluation, and inference, so the researchers focused on four subskills, which are fundamental to critical thinking according to Facione, because this targeting was considered suitable for students' critical thinking skills in the polynomials course.

This study proposed an intervention involving openended questions and activities based on student learning preferences, which aims to (1) study and classify the classroom activities that support students' learning in mathematics and (2) develop students' mathematical critical thinking skills at the different performance levels in polynomials that focus on the four subskills of interpretation, analysis, evaluation, and inference.

\section{Materials and Methods}

2.1. Research Design and Sampling. After obtaining permission from King Mongkut's University of Technology Thonburi Board (KMUTT-IRB-COA-2021-007), the study was implemented with an embedded mixed-method design from April to May 2021 at a high school in Bangkok, Thailand. The participants were 98 seventh-grade students (three classes) in their second semester. Before the classes were selected, researchers analyzed the homogeneity of variance and the equality of means of students by mathematics scores from the first semester. The variance for the three classes was equal $(0.94>0.05)$, and the mean difference did not statistically significantly differ at the 0.05 level $(0.56>0.05)$. Because these three classes were not statistically different, one class of 32 students was chosen as a sample. However, due to missing data, some students needed to be omitted, so the sample size fell to 28 students, who were divided into three groups: high achievement, fair achievement, and low achievement.

2.2. Procedures. The content of the instruction used for this study involved the addition, subtraction, multiplication, and division of the polynomials. The researchers 
collected data in two phases. In Phase I, the researchers employed Google Forms to collect students' demographic data and mathematics scores in the first semester, as well as the activities in which students prefer to participate. The data about developing critical thinking skills in polynomials were collected in Phase II; the data on activities that supported student learning preferences were obtained from the students' responses in Phase I and were employed in designing the lesson plans. The intervention took place over 12 periods (two periods/week). Each student sat at a single desk typically arranged in rows and columns. When doing pair or group work, students occasionally shifted their desks to work together. Before finishing the class, students were given exit tickets to give learning feedback. Students were given a pretest before the intervention began, and a posttest was given after completing the interventions. Five students were selected by convenience sampling for interviews about the polynomial questions to observe students' mathematical critical thinking skills during the fifth and eleventh periods. Table 1 shows the teaching process.

The sample activity is one example of the open-ended activities to support student learning preferences to develop the targeted critical thinking subskills (see Figure 1). In this example, students were divided into groups of four to solve the problem. "This is a set of jigsaws that represent the field of Abang's farm, which includes a strawberry field, a tomato field, a cabbage field, and a garlic field. I would like to create two ditches on the farm that make in the letter T. Abang told me that "the area and perimeter of each ditch are the same" Do you believe him? Why?"

An excerpt taken from a typical lesson is given below. "T" represents the teacher, and " $\mathrm{S}$ " represents the students. The excerpt contains the open-ended questions in the discussion section after students solved the problem with their group (see Table 2).

2.3. Instruments. In Phase I, the instrument comprised an item with open-ended questions "What kind of classroom activities are suitable for you and support your learning? State your reason." to obtain critical information for developing the lesson plans. In Phase II, the researchers developed a critical thinking skills test in polynomials to determine how the intervention affected students' skills. The test consisted of nine multiple-choice items with five options to measure interpretation and analysis in polynomials and two essay items to measure evaluation and inference. Exit tickets were used to obtain students' feedback. The questions in the exit ticket are as follows:

(1) "Did today's activities help you learn? Why?"

(2) "Do you think you think more carefully than before when you learn in my class? Why?"

The structured interview on polynomials was used to observe the development of critical thinking subskills during treatment in the fifth and eleventh periods. The questions used in the interview were as follows:
(1) "Multiplication between a monomial and a polynomial can be illustrated by finding the area of a rectangle." Do you agree with this statement?

(2) Do you think your friends would answer this question the same as you did or differently? Why?

The content validity of the instruments was assessed by five experts in mathematics, mathematics education, and measurement/evaluation in education. All of the instruments were then revised based on the experts' opinion. The item-objective congruence was $0.60-1.00$. After instrument validation, the skills test and structured interview prompts were pilot tested by 30 eighth graders in the same junior high school, and the results were analyzed. The difficulty index ranged between 0.25 and 0.79 , discriminative power ranged between 0.25 and 0.75 , and the reliability verified through Cronbach's alpha was found to be 0.65 . Table 3 illustrates the common components of the questions that provide an opportunity to think critically about polynomials.

2.4. Data Analysis Techniques. The content analysis technique was used to analyze the qualitative data obtained from the responses about student learning preferences, experts' and eighth-graders' suggestions from the pilot testing, feedback from the exit tickets, and interview results. For the quantitative data, pre- and post-test results were analyzed with normal distribution using the Shapiro-Wilk test, which suggested a normal distribution, as the significant value must be more than 0.05 . Second, the hypothesis about the development of critical thinking skills related to polynomials among seventh graders was tested using the dependent $t$-test and descriptive statistics, such as means, standard deviations, and percentage. Data from the test were analyzed by calculating percentages to assess the level of critical thinking skills following Firdaus et al. (2015), as shown in Table 4.

\section{Results}

3.1. Quantitative Data. The Phase I results in Table 5 show that 11 low-achieving students, 7 fair-achieving students, and 3 high-achieving students preferred to participate in fun learning activities that can be applied in daily life, as well as engaging with teachers who understand the students. There were four low-achieving students and one high-achieving student who preferred speaking and listening activities. One low-achieving student preferred visual activities, and another low-achieving student preferred reading/writing activities.

For Phase II, Table 6 shows the means and standard deviations for low-achieving students' mathematical critical thinking subskills; before treatment, interpretation $(M=0.647, \mathrm{SD}=0.786)$ and analysis $(M=1.941, \mathrm{SD}=1.197)$ were poor, and evaluation $(M=0.353, \mathrm{SD}=0.606)$ and inference $(M=0.353, \mathrm{SD}=0.786)$ were very poor. After treatment, interpretation $(M=1.118, \mathrm{SD}=1.054)$ and inference $(M=1.529, \mathrm{SD}=1.586)$ were poor, and analysis $(M=2.588, \quad \mathrm{SD}=1.698)$ and evaluation $(M=1.235$, $\mathrm{SD}=1.091)$ were fair. Overall, the critical thinking skills 
TABLE 1: Outline of the teaching process.

\begin{tabular}{|c|c|c|}
\hline $\begin{array}{l}\text { Time in } \\
\text { minutes }\end{array}$ & Process of teaching using open-ended questions & $\begin{array}{l}\text { Instruments or activities to support students' } \\
\text { learning preferences }\end{array}$ \\
\hline \multirow{3}{*}{5} & Introducing the session by showing the problems or reviewing the & (1) Visual supported \\
\hline & previous knowledge of polynomials & (i) Symbol of algebra tiles \\
\hline & Conducting the activities that are related to their daily life & (ii) Highlight the necessary things \\
\hline \multirow[t]{2}{*}{15} & (i) Individual work & (iii) Flashcards \\
\hline & (ii) Pair/group work & (2) Aural supported \\
\hline 15 & Discussion of the results & (i) Open-ended questions \\
\hline \multirow[t]{6}{*}{10} & Students and teachers help to summarize & (ii) Think/pair/share activities \\
\hline & & (3) Read/write support \\
\hline & & (i) Worksheets \\
\hline & & (ii) Flashcards \\
\hline & & (4) Kinesthetic supported \\
\hline & & (i) Algebra tiles to explain the polynomials \\
\hline \multirow[t]{5}{*}{5} & Students complete the exit ticket & ${ }^{*}$ Activities to support all learning preferences \\
\hline & & (i) Bingo \\
\hline & & (ii) Roleplaying as a teacher to determine the \\
\hline & & $\begin{array}{l}\text { correctness of given solutions } \\
\text { (iii) } \mathrm{T} \text { puzzle }\end{array}$ \\
\hline & & ${ }^{*}$ When summarizing, using Wonder Go or Kahoot \\
\hline
\end{tabular}

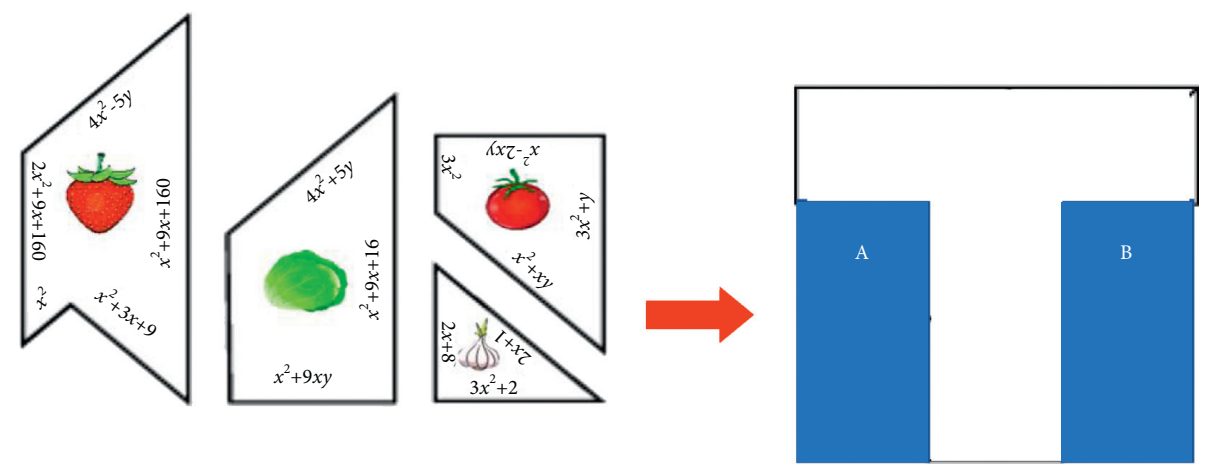

FIGURE 1: Illustration of sample activity.

(from the mean of the four subskills) among low-achieving students in the posttest remained poor.

Table 7 shows the means and standard deviations for fair-achieving students' mathematical critical thinking subskills. Before treatment, interpretation $(M=1.143$, $\mathrm{SD}=0.900)$ and analysis $(M=1.429, \mathrm{SD}=1.272)$ were poor, and evaluation $(M=0, \mathrm{SD}=0)$ and inference $(M=0, \mathrm{SD}=0)$ were very poor. After treatment, interpretation $(M=1.857$, $\mathrm{SD}=1.069)$ was good, analysis $(M=3.571, \mathrm{SD}=1.397)$ and evaluation $(M=1.571, \mathrm{SD}=0.787)$ were fair, and inference $(M=1.857, \mathrm{SD}=0.900)$ was the only subskill at the poor level. Overall, the critical thinking skills among fairachieving students in the posttest improved from poor to fair.

Table 8 shows the mean and standard deviations for high-achieving students' mathematical critical thinking subskills. Before treatment, interpretation $(M=0.250$, $\mathrm{SD}=0.500)$, evaluation $(M=0.500, \mathrm{SD}=0.577)$, and inference $(M=0.250, \mathrm{SD}=0.500)$ were very poor. Analysis $(M=2.500, \mathrm{SD}=1.291)$ was the only subskill at the poor level. After treatment, all subskills were fair. Overall, the critical thinking skills among high-achieving students in the posttest improved from very poor to fair.
Table 9 shows that the increase in pre- and post-test scores among low-achieving students is 4.734 , and the $t$-test showed a significant difference in mean improvement between pre- and post-test scores among low-achieving students (Sig. <0.05). The increase from pre-test to post-test scores among fair-achieving students is 6.286, and the $t$-test showed a significant difference in mean improvement (Sig. $<0.05)$. The increase in pre-test and post-test scores among high-achieving students is 6.000 , and the $t$-test showed a significant difference in the mean improvement (Sig. < 0.05). The results indicate that students' performance improved after the use of open-ended questions and activities based on student learning preferences.

3.2. Qualitative Data. Five students participated in 1-on-1 interviews, and the researcher noticed that all students at different performance levels were guided by the "What do you see in the picture?" activity (Figure 2) to practice interpreting and reasoning. In the second interview, there were four out of five students-two high-achieving students, one fair-achieving student, and one low-achieving student-who could analyze and solve the problem based on 
TABLE 2: Use of open-ended questions in intervention.

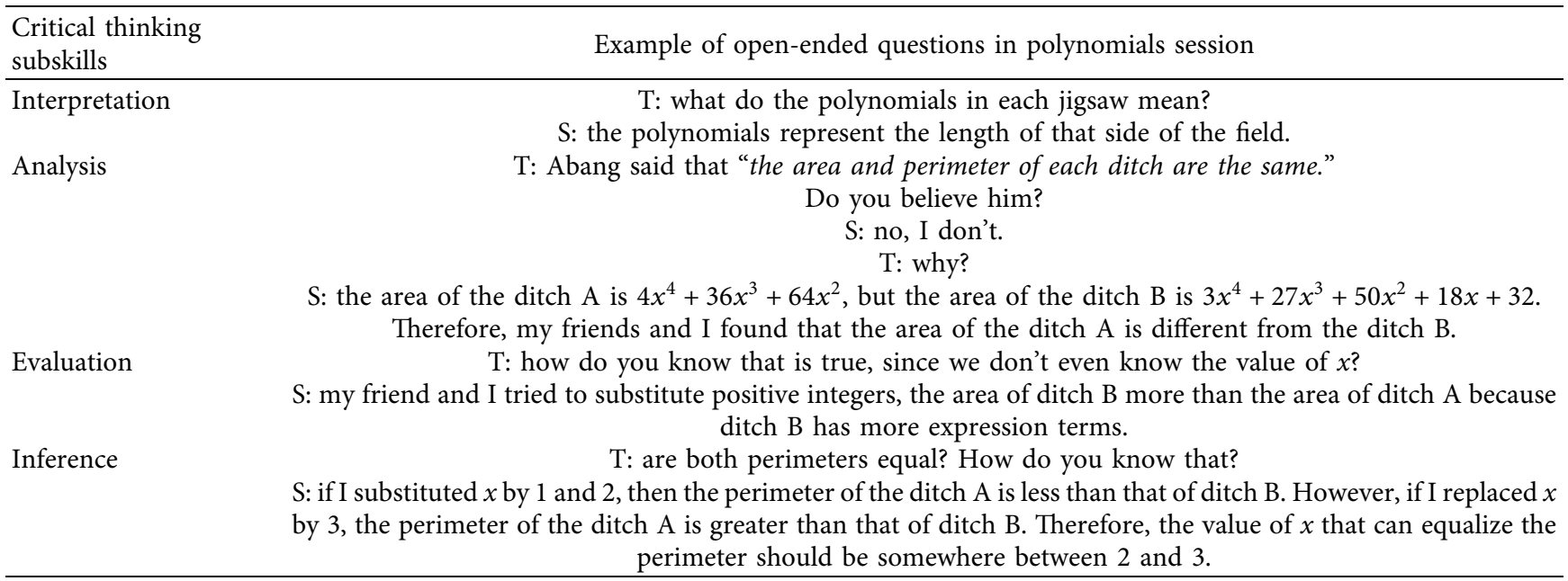

TABle 3: Sample test question.

Sample question of the test to develop critical thinking skills in polynomials

Consider the statements in each item below. Which do you think is the correct answer?

(a)

$$
\begin{gathered}
\left(\left(4 x^{2}-15 x\right) /-x\right)= \\
4 x-15 x=-9 x
\end{gathered}
$$

(1) a

(2) b

(b) $\left(\left(-4 x^{2}-15 x\right) /-x\right)=4 x+15$

(3) c

(c) $\left(\left(-4 x^{2}+15 x\right) /-x\right)=-4 x-15$

(4) All of these above

(5) None
TABLE 4: Score range for rating mathematical critical thinking skills [35].

\begin{tabular}{lc}
\hline Range of score $\%$ & Students' critical thinking skills \\
\hline $80-100$ & Excellent \\
$60-79$ & Good \\
$40-59$ & Fair \\
$20-39$ & Poor \\
$0-19$ & Very poor \\
\hline
\end{tabular}

the picture, as well as being able to predict what their peers' answers would be based on their learning. However, there was only one low-achieving student who understood the basic knowledge and could only answer the teacher's guided questions; when asked to solve the problem individually, the student could not apply the knowledge learned in the class. According to the observation, there was a big difference in behavior in the first and second 1-on-1 interviews. Students were encouraged to express their opinions, and although the five students were at three different performance levels, we observed that they tried their best to answer and give their reasons based on what they had learned.

Table 10 shows excerpt taken from the interview results. " $\mathrm{T}$ " represents the teacher, " $\mathrm{H}$ " represents high-achieving students, "F" represents fair-achieving students, and " $L$ " represents low-achieving students.

The data obtained from the exit tickets indicate that fun activities and instruments adjusted to students' learning preferences could help students at all performance levels participate in mathematics class. Additional data are shown below.

Low-achieving 2: "Yes, it can help us because a teacher had a game inserted, and a mobile phone came in for us to use in the class. Because we are modern, we must keep up with technology, unlike other teachers who use only books."

Low-achieving 4: "Yes, because you can make me understand."

Fair-achieving 2: "Yes, it can help me apply knowledge to consider daily life skills."

Fair-achieving 3: "It helped me to learn to understand because I can use my smartphone to learn with your activity."

High-achieving 1: "Yes, because it is more fun than just watching a teacher speak for 50 minutes straight; I think it is enjoyable."

High-achieving 2: "It helped me understand monomials using the Algebra tile visual tools quickly."

In addition, the teaching process could help them think carefully before making judgments because the open-ended questions challenged them. The following are some of the students' answers.

High-achieving 3: "Yes, because when I have studied the monomial, it was challenging and complex, but it made me think more carefully when the teacher used more questions than before."

Fair-achieving 3: "Yes, I think about being more careful about the activity."

Low-achieving 6: "Yes, because the teacher's activities tricked me every class."

Low-achieving 9: "Yes, because the teacher's activities made me think more carefully, because it is complex." 
TABLE 5: Number of students at different performance levels and learning preferences.

\begin{tabular}{|c|c|c|c|c|}
\hline \multirow[t]{2}{*}{ Preferred activities (content analysis) } & \multicolumn{3}{|c|}{$\begin{array}{l}\text { Student } \\
\text { performance } \\
\text { levels }\end{array}$} & \multirow[t]{2}{*}{ Preferences } \\
\hline & Low & Fair & High & \\
\hline $\begin{array}{l}\text { (1) Students who like to participate in fun learning activities that can be us } \\
\text { understand the students. } \\
\text { "I love the activities that are like a game." } \\
\text { "I love the activities that involve competition." } \\
\text { "I love hands-on activities." } \\
\text { "I love exciting classes, fun activities." } \\
\text { "I would like fun activities and a teacher who understands me." } \\
\text { "I love a teacher who instructs by using fun activities relevant to daily life." }\end{array}$ & 11 & 7 & 3 & $\mathrm{~K}$ \\
\hline $\begin{array}{l}\text { (2) Students who like to speak and listen in the class. } \\
\text { "I love to listen to everything that the teacher explains." } \\
\text { "I love to speak and share my ideas in class." } \\
\text { "I love the teacher who explains content clearly." }\end{array}$ & 4 & 0 & 1 & A \\
\hline $\begin{array}{l}\text { (3) Students who like to watch from the symbols, colorful letters, graphs. } \\
\text { "I love to see the symbols that make me easy to understand." }\end{array}$ & 1 & 0 & 0 & $\mathrm{~V}$ \\
\hline $\begin{array}{l}\text { (4) Students who like to read and write from the textbook, worksheet. } \\
\text { "I love to read from the book." }\end{array}$ & 1 & 0 & 0 & $\mathrm{R}$ \\
\hline
\end{tabular}

TABle 6: Low-achieving: means and standard deviations for and pre- and post-test scores.

\begin{tabular}{|c|c|c|c|c|c|c|}
\hline \multirow{2}{*}{ Critical thinking subskills } & \multirow{2}{*}{$N$} & \multirow{2}{*}{ Maximum score } & \multicolumn{2}{|c|}{ Pretest } & \multicolumn{2}{|c|}{ Posttest } \\
\hline & & & Mean & $\mathrm{SD}$ & Mean & SD \\
\hline Interpretation & 17 & 3 & $0.647(21.569 \%)$ & 0.786 & $1.118(37.255 \%)$ & 1.054 \\
\hline Analysis & 17 & 6 & $1.941(32.353 \%)$ & 1.197 & $2.588(43.137 \%)$ & 1.698 \\
\hline Evaluation & 17 & 3 & $0.353(11.765 \%)$ & 0.606 & $1.235(41.176 \%)$ & 1.091 \\
\hline Inference & 17 & 6 & $0.353(5.882 \%)$ & 0.786 & $1.529(25.490 \%)$ & 1.586 \\
\hline Overall & 17 & 18 & $2.701(15.010 \%)$ & 1.993 & $6.760(37.556 \%)$ & 4.002 \\
\hline
\end{tabular}

TABLE 7: Fair-achieving: means and standard deviations for pre- and post-test scores.

\begin{tabular}{|c|c|c|c|c|c|c|}
\hline \multirow{2}{*}{ Critical thinking subskills } & \multirow{2}{*}{$N$} & \multirow{2}{*}{ Maximum score } & \multicolumn{2}{|c|}{ Pretest } & \multicolumn{2}{|c|}{ Posttest } \\
\hline & & & Mean & $\mathrm{SD}$ & Mean & SD \\
\hline Interpretation & 7 & 3 & $1.143(38.095 \%)$ & 0.900 & $1.857(61.095 \%)$ & 1.069 \\
\hline Analysis & 7 & 6 & $1.429(23.810 \%)$ & 1.272 & $3.571(59.524 \%)$ & 1.397 \\
\hline Evaluation & 7 & 3 & $0(0 \%)$ & 0.000 & $1.571(52.381 \%)$ & 0.787 \\
\hline Inference & 7 & 6 & $0(0 \%)$ & 0.000 & $1.857(30.952 \%)$ & 0.900 \\
\hline Overall & 7 & 18 & $2.571(14.286 \%)$ & 1.718 & $8.857(49.206 \%)$ & 3.024 \\
\hline
\end{tabular}

Low-achieving 10: "Yes, because the teacher has activities that made me think."

Low-achieving 11: "Yes, because the worksheets made me be careful before answering the question."

\section{Discussion}

Based on the results from Phase I, as shown in Table 5, most students at all performance levels dislike visual and reading/writing activities because they are generally accustomed to learning via a teacher-centered approach, in which the main activities are writing, listening, and watching the teacher's instruction, with less interaction between students and teacher. According to the information obtained from the exit tickets, during the intervention, students had more interaction and enjoyment in the classroom than in traditional classroom management settings. These findings are supported by the suggestions of Khongpit et al. that the teacher should design a variety of activities to appropriately support student learning preferences and encourage student participation [28, 29, 31]. Tan found that many students prefer a teacher-centered approach, but in this study, students did not prefer teachercentered methods, but they did have distinct learning styles in class [33]. Phantharakphong found that high-achieving students tend to prefer activities that involve learning by doing and apply to daily life, while low-achieving students tend to prefer a variety of activities that include visual, speaking, and listening activities, as well as writing activities [32]. In the present study, however, low-achieving students also preferred activities normally favored by highachieving students. 
TABLE 8: High-achieving: means and standard deviations for pre- and post-test scores.

\begin{tabular}{|c|c|c|c|c|c|c|}
\hline \multirow{2}{*}{ Critical thinking subskills } & \multirow{2}{*}{$N$} & \multirow{2}{*}{ Maximum score } & \multicolumn{2}{|c|}{ Pretest } & \multicolumn{2}{|c|}{ Posttest } \\
\hline & & & Mean & $\mathrm{SD}$ & Mean & SD \\
\hline Interpretation & 4 & 3 & $0.250(8.333 \%)$ & 0.500 & $1.500(50.00 \%)$ & 0.577 \\
\hline Analysis & 4 & 6 & $2.500(41.667 \%)$ & 1.291 & $4.000(66.667 \%)$ & 0.816 \\
\hline Evaluation & 4 & 3 & $0.500(16.667)$ & 0.577 & $1.500(50.000 \%)$ & 1.291 \\
\hline Inference & 4 & 6 & $0.250(4.167 \%)$ & 0.500 & $2.500(41.667 \%)$ & 3.000 \\
\hline Overall & 4 & 18 & $3.500(19.444 \%)$ & 2.517 & $9.500(52.778 \%)$ & 4.123 \\
\hline
\end{tabular}

TABle 9: Dependent $t$-test on critical thinking skills of students at all performance levels.

\begin{tabular}{|c|c|c|c|c|c|c|}
\hline Period & $N$ & $\begin{array}{c}\text { Maximum } \\
\text { score }\end{array}$ & $\begin{array}{l}\text { Difference between pre- and post-test } \\
\text { scores }\end{array}$ & $\begin{array}{l}\text { Standard } \\
\text { deviation }\end{array}$ & $t$ & $p$ \\
\hline $\begin{array}{l}\text { Pretest-posttest of students at low } \\
\text { performance }\end{array}$ & 17 & 18 & 4.734 & 3.940 & 4.955 & $0.000^{*}$ \\
\hline $\begin{array}{l}\text { Pretest-posttest of students at fair } \\
\text { performance }\end{array}$ & 7 & 18 & 6.286 & 3.946 & 4.214 & $0.006^{*}$ \\
\hline $\begin{array}{l}\text { Pretest-posttest of students at high } \\
\text { performance }\end{array}$ & 4 & 18 & 6.000 & 2.828 & 4.243 & $0.024^{*}$ \\
\hline
\end{tabular}

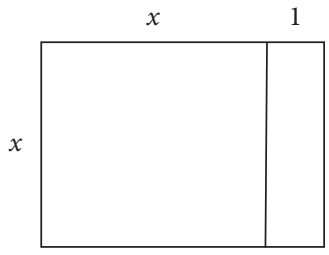

FIGURE 2: Illustration for a question used in the interview.

According to the descriptive analysis, inferential analysis, and interview results in Phase II, the level of students' critical thinking subskills (interpretation, analysis, evaluation, and inference) at all performance levels had improved after the intervention using open-ended questions and activities based on student learning preferences. These findings are supported by Plianrama et al. that open-ended questions can help to develop mathematical critical thinking skills $[34,47,48]$.

Students at all performance levels can positively develop critical thinking skills in solving polynomials problems, by practicing decision-making based on reasoning and experience to find appropriate answers. Students require various activities to aid learn in with teacher support; having the opportunity to choose how to learn is a benefit to students, which is in line with Tan, who found that students can adapt and choose appropriate ways to learn in class [33]. It is also supported by Singweratham and Munroe, who found that activities provide an environment conducive to learning that encourages students to seek and build knowledge on their own through cooperation and interaction with peers $[30,53]$. The open-ended questions and activities in the present intervention taught students how to think with mathematics beyond memorization. These results are in line with $\mathrm{Su}$ et al., as the process of thinking through math helps students think critically, discover relationships and patterns of mathematical content, innovate, and create new ideas [36]. The results shown in Table 9 illustrate that the critical thinking skills of the high- and fair-achieving students were at the same level after the intervention, which is a novel finding, as Zetriuslita et al. found that students at different performance levels tend to develop critical thinking skills to differential levels; that is, the high-achieving students can have the potential to develop the highest level of critical thinking skills [54-57].

Results for each subskill, shown in Tables 6-8, indicate that analysis yielded the highest level among high- and lowachieving students. According to Firdaus et al., teachers should allow students to explore and plan to solve problems related to their daily life. The highest scores for fairachieving students were found for interpretation because, in this study, open-ended questions were used with pictures or visual aids to support interpretation $[35,56]$. According to Aziza et al., students practice identifying problems, determine and map what is known, and, after being guided by the use of questions, can visualize the problem $[50,53,56]$. However, the results also show that the lowest critical thinking subskill for the students at the three different performance levels is inference, which is in line with Basri et al. [51, 56].

Critical thinking skills are essential for secondary students because they face related problems in their daily life. This is in line with Facione et al.'s belief; that is, critical thinking is both an academic and a life skill $[3,48]$. Using open-ended questions and activities based on student learning preferences is thus one of the instruction methods best suited to preparing secondary students to meet the demands of the 21st century. Although the open-ended questions and activities based on student learning preferences developed students' critical thinking skills at all performance levels, this study has limitations. First, only male students participated in this study. Second, the research instrument focused on mathematical critical thinking skills related to polynomials using only four subskills, so future studies could consider a different range of subskills. We also 


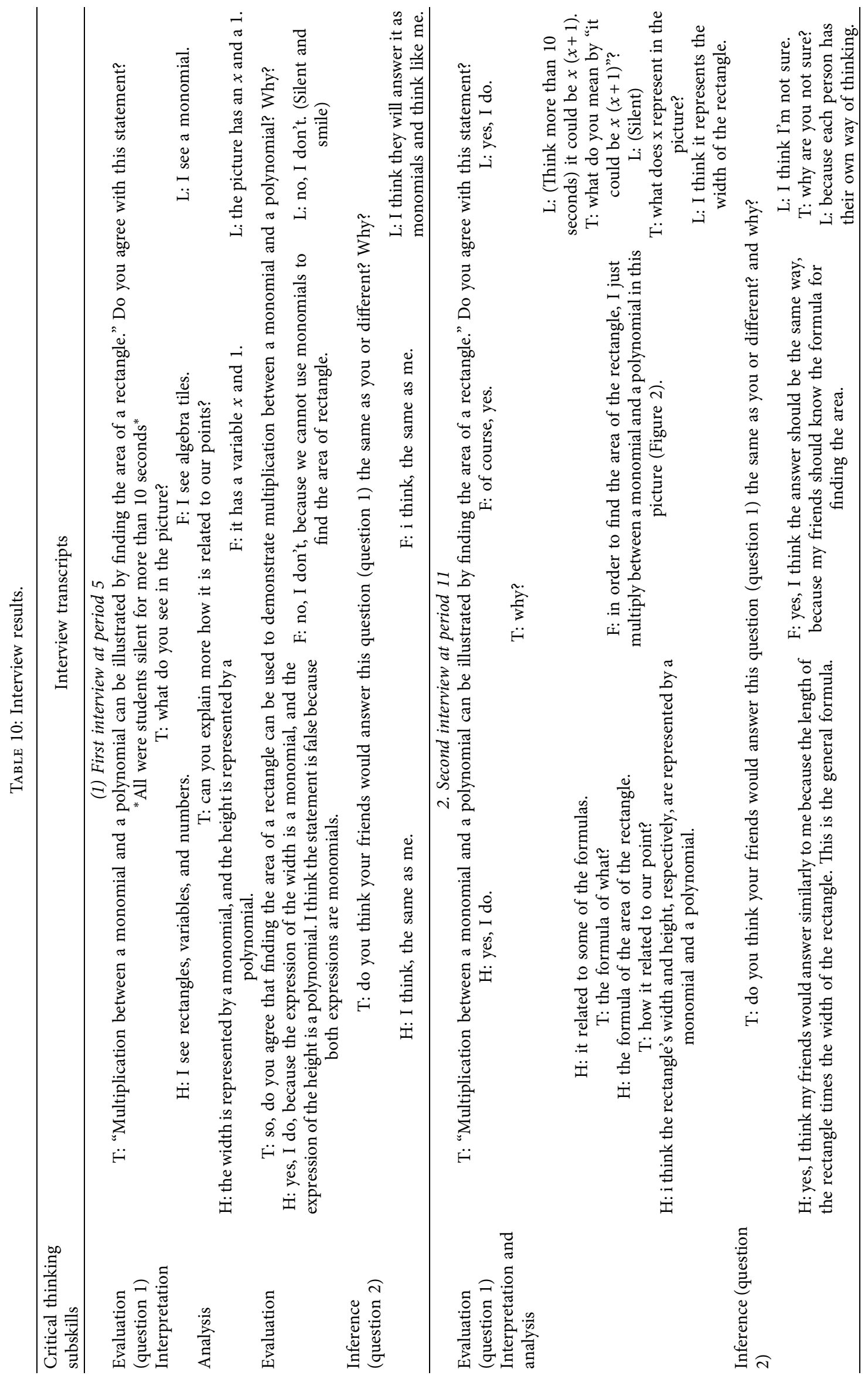


recommend that future studies include female students and replicate the present study to allow comparison in the use of open-ended questions and activities based on student learning preferences, as well as traditional teaching approaches, for students at different performance levels. The use of open-ended questions and activities based on student learning preferences could also be used for instruction in different mathematics topics.

\section{Conclusions}

Open-ended questions and activities based on student learning preferences can help in developing students' critical thinking skills related to polynomials at all performance levels. Students tended to prefer activities that allowed them to learn by practicing and that involved discussion more than reading/writing and visual activities. However, this study did not assess all critical thinking subskills, so subsequent research could seek to determine all critical thinking subskills among secondary students and increase the sample using open-ended questions and activities based on student learning preferences.

\section{Data Availability}

The data are available from the corresponding author upon reasonable request.

\section{Conflicts of Interest}

The authors declare that they do not have any conflicts of interest regarding the publication of this paper.

\section{Acknowledgments}

The authors would like to express their great appreciation to Mr. Nandana Indananda for the facilities that supported this research. The authors also thank LetPub (http://www.letpub. com) for its linguistic assistance during the preparation of this manuscript. This research was funded by the Petchra Pra Jom Klao Master's Degree Research Scholarship from King Mongkut's University of Technology Thonburi (Grant no. 10/2562).

\section{References}

[1] Office of the Education Council, Education in Thailand, Office of the Education Council Ministry of Education, Bangkok, Thailand, 2017.

[2] O. L. Uribe-Enciso, D. S. Uribe-Enciso, and M. D. P. VargasDaza, "Critical thinking and its importance in education," Rastros Rostros, vol. 19, 2018.

[3] P. Facione, "Critical thinking: what it is and why it counts," 2020, https://www.insightassessment.com/article/criticalthinking-what-it-is-and-why-it-counts.

[4] S. Habibah, R. Setyowati, and M. Mustika, "Improving critical thinking skills of students through the development of teaching materials," 2018, https://www.researchgate.net/ publication/330237904_Improving_Critical_Thinking_ Skills_of_Students_through_the_Development_of_ Teaching_Materials.
[5] S. Mongkhondao, Critical Thinking and Teaching Impact, Thammasat Niversity, Bangkok, Thailand, 2015.

[6] West Virgina Department of Education, Survey of Employer Skill Needs, West Virgina Department of Education, Charleston, WV, USA, 2019.

[7] National Association of Colleges and Employers, Empolyers Rate Career Competencies, New Hire Proficiency, National Association of Colleges and Employers, Bethlehem, PA, USA, 2017.

[8] S. Rochanasak, R. Klinjuy, S. Samanit, and V. Nilamai, "Essential skills for Thailand 4.0: the importance of education corresponded to employment scenarios, and building selfcompetent immunity pertaining to technological disruptions," Veridian E-Journal, Silpakorn University, vol. 12, 2019.

[9] J. Y. F. Lau, An Introduction to Critical Thinking and Creativity: Think More, Think Better, John Wiley \& Sons, Inc., Hoboken, NJ, USA, 2011.

[10] U. Turan, Y. Fidan, and C. Yıldıran, "Critical thinking as a qualified decision making tool," Journal of History Culture and Art Research, vol. 8, no. 4, p. 1, 2019.

[11] J. Dewey, How We Think. 1910, D.C. Heath \& Co, Boston, MA, USA.

[12] R. Ennis, "Critical thinking across the curriculum: a vision," Topoi, vol. 37, 2018.

[13] E. M. Glaser, An Experiment in the Development of Critical Thinking, Teachers College, Columbia University, New York, NY, USA, 1941.

[14] D. Hitchcock, "Critical thinking as an educational ideal," in Proceedings of the 2011 Conference on Critical Thinking and Education, Wuhan, China, 2011.

[15] A. N. Chukwuyenum, "Impact of critical thinking on performance in mathematics among senior secondary school students in Lagos state," IOSR Journal of Research \& Method in Education (IOSRJRME), vol. 3, no. 5, pp. 18-25, 2013.

[16] L. Yuliati, R. Fauziah, and A. Hidayat, "Student's critical thinking skills in authentic problem based learning," Journal of Physics: Conference Series, vol. 1013, Article ID 012025, 2018.

[17] Office of the Basic Education Commission, Thailand Country Note Results, Office of the Basic Education Commission, Bangkok, Thailand, 2018.

[18] Y. Al-Rababaha, W. T. Yew, and C. C. Meng, "Misconceptions in school algebra," International Journal of Academic Research in Business and Social Sciences, vol. 10, 2020.

[19] J. Booth, C. A. Barbieri, F. Eyer, and E. J. Paré-Blagoev, "Persistent and pernicious errors in algebraic problem solving," Journal of Problem Solving, vol. 7, pp. 10-23, 2014.

[20] J. Khawsuk and K. Srihaset, "The development of a mathematics diagnostic test for polynomialsat the matthayom sueksa one level," Veridian E-Journal, Silpakorn University, vol. 9, 2016.

[21] K. Kurniati, Y. S. Kusumah, J. Sabandar, and T. Herman, "Mathematical critical thinking ability through contextual teaching and learning approach," Journal on Mathematics Education, vol. 6, no. 1, pp. 53-62, 2015.

[22] V. Israsena, “Thai teachers' belifes about leaner-centered education: implications for success for life Thailand," in Doctor of EducationUniversity of North Texas, Denton, TX, USA, 2007.

[23] Y. Phungphol, "Learner-centered teaching approach: a paradigm shift in Thai education," ABAC Journal, vol. 25, 2015.

[24] N. Fleming, "I'm different; not dumb: modes of presentation (V.A.R.K.) in the tertiary classroom," in Proceedings of the 1995 Annual Conference of the Higher Education and Research 
Development Society of Australasia (HERDSA), Rockhampton, Australia, 1995.

[25] N. Fleming and D. Baume, "Learning styles again: VARKing up the right tree!" Educational Developments, pp. 4-7, SEDA Ltd, Putrajaya, Malaysia, 2006.

[26] N. Fleming and C. Bonwell, How Do I Learn Best, 2019, https://vark-learn.com/wp-content/uploads/2019/07/HowDo-I-Learn-Best-Sample.pdf.

[27] Y. Aprita and A. Sari, "Improving students' motivation of learning using blended learning strategy facilitated with VARK learning style model," Jurnal Pendidikan Akuntansi Indonesia, vol. 12, 2014.

[28] V. Khongpit, K. Sintanakul, and T. Nomphonkrang, "The VARK learning style of the university student in computer course," International Journal of Learning and Teaching, vol. 4, no. 2, pp. 102-106, 2018.

[29] M. Mat Halif, N. Hassan, N. A. Sumardi et al., "Moderating effects of student motivation on the relationship between learning styles and student engagement," Asian Journal of University Education, vol. 16, no. 2, p. 93, 2020.

[30] N. Singweratham, "The development of an instructional model based on didactic teaching by using VARK learning styles on analytical thinking," The Southern College Network Journal of Nursing and Public Health, vol. 6, 2019.

[31] A. Watcharawiwat, S. Bunmusik, J. Suwanjaroen, P. Yamanantakul, and S. Ploypet, "Relations between VARK learning style model and GPAX of nursing students at the boromarajonani college of nursing in Suratthani," The Southern College Network Journal of Nursing and Public Health, vol. 7, pp. 283-294, 2020.

[32] P. Phantharakphong, "English learning styles of high and low performance students of the faculty of education, Khon Kaen University," Procedia-Social and Behavioral Sciences, vol. 46, pp. 3390-3394, 2012.

[33] H. Tan, "Are mathematics students' learning styles related to their preferred method of learning how to use advanced calculators?" in Proceedings of the Asian Technology Conference in Mathematics (ATCM) 2016, pp. 250-259, Mathematics and Technology LLC: Pattaya, Bangkok, Thailand, 2016.

[34] S. Plianram and M. Inprasitha, "Study of critical thinking in open-ended mathematical problem-solving situation," KKU Research Journal (Graduate Studies), vol. 7, 2007.

[35] F. Firdaus, I. Kailani, M. N. B. Bakar, and B. Bakry, "Developing critical thinking skills of students in mathematics learning," Journal of Education and Learning (EduLearn), vol. 9, no. 3, pp. 226-236, 2015.

[36] H. F. H. A. Su, F. A. Ricci, and M. Mnatsakanian, "Mathematical teaching strategies: pathways to critical thinking and metacognition," International Journal of Research in Education and Science, vol. 2, no. 1, p. 190, 2015.

[37] C. Cresswell and C. P. Speelman, "Does mathematics training lead to better logical thinking and reasoning? A cross-sectional assessment from students to professors," PLoS One, vol. 15, no. 7, Article ID e0236153, 2020.

[38] S. Syafril, N. R. Aini, Netriwati, A. Pahrudin, N. E. Yaumas, and Engkizar, "Spirit of mathematics critical thinking skills (CTS)," Journal of Physics: Conference Series, vol. 1467, no. 1, Article ID 012069, 2020.

[39] R. Runisah, T. Herman, and J. Dahlan, "The enhancement of students' critical thinking skills in mathematics through the 5E learning cycle with metacognitive technique," in Proceedings of the 2017 International Conference on Mathematics and Science Education, Malang, Indonesia, 2017.
[40] C. Evans, Measuring Student Success Skills: A Review of the Literature on Critical Thinking, Center for Assessment, Dover, NH, USA, 2020.

[41] A. Johnson, C. McKay-Jackson, and G. Grumbach, Critical Service Learning Toolkit: Social Work Strategies for Promoting Healthy Youth Development, Oxford University Press, Oxford, UK, 2017.

[42] C. Neely, All about Open-Ended Questions, Teacherstone, Charlottesville, VA, USA, 2019.

[43] M. Songserm, P. Thongsorn, and W. Chaturanon, "The development of biology instructional model to enhance analytical thinking critical thinking and problem solving thinking skills of Matthayom Suksa six students," Journal of Education Narasuan University, vol. 22, pp. 175-189, 2019.

[44] T. Santoso, L. Yuanita, and E. Erman, "The role of student's critical asking question in developing student's critical thinking skills," Journal of Physics: Conference Series, vol. 953, Article ID 012042, 2018.

[45] H.-H. Wu, "The role of open-ended problems in mathematics education," Journal of Mathematical Behavior, vol. 13, 2000.

[46] W. M. W. Yusof and S. C. Seman, "Teachers' knowledge of higher order thinking and questioning skills: a case study at a primary school in Terengganu," Malaysia International Journal of Academic Research in Progressive Education and Development, vol. 7, 2018.

[47] A. Palinussa, "Students' critical mathematical thinking skills and character:experiments for junior high school students through realistic mathematics education culture-based," Journal on Mathematics Education, vol. 4, 2013.

[48] W. Winarso and P. Hardyanti, "Using the learning of reciprocal teaching based on open ended to improve mathematical critical thinking ability," Eduma Mathematics Education Learning and Teaching, vol. 8, pp. 11-24, 2019.

[49] H. Çakır Sarı and Ö. Cengiz, "The use of open ended versus closed ended questions in Turkish classrooms," Open Journal of Modern Linguistics, vol. 06, pp. 60-70, 2016.

[50] M. Aziza, "The use of open-ended question pictures in the mathematics classroom," New Trends and Issues Proceedings on Humanities and Social Sciences, vol. 4, p. 1, 2017.

[51] H. Basri, Purwanto, A. R. As'ari, and Sisworo, "Investigating critical thinking skill of junior high school in solving mathematical problem," International Journal of Instruction, vol. 12, no. 3, pp. 745-758, 2019.

[52] H. Husain, B. Bais, A. Hussain, and S. A. Samad, "How to construct open ended questions," Procedia-Social and Behavioral Sciences, vol. 60, pp. 456-462, 2012.

[53] L. Munroe, "Observations of classroom practice. Using the open approach to teach mathematics in a grade six class in Japan," in Proceedings of the 7th ICMI-East Asia Regional Conference on Mathematics Education, pp. 347-355, Cebu, Philippines, 2015.

[54] H. Zetriuslita, R. Ariawan, and H. Nufus, "Students' critical thinking ability: description based on academic level and gender," Journal of Education and Practice, vol. 7, 2016.

[55] S. Chaiyawan and D. Katwibun, "An analysis of students' critical thinking in a mathematics classroom implementing an open approach," Journal of Research Methodology, vol. 27, 2014.

[56] S. Y. Seventika, Y. L. Sukestiyarno, and S. Mariani, "Critical thinking analysis based on Facione (2015)-Angelo (1995) logical mathematics material of vocational high school (VHS)," Journal of Physics: Conference Series, vol. 983, Article ID 012067, 2018. 
[57] M. Zayyadi, T. Nusantara, E. Hidayanto, I. M. Sulandra, and A. R. As'ari, "Exploring prospective student teacher's question on mathematics teaching practice," Journal of Technology and Science Education, vol. 9, no. 2, pp. 228-237, 2019.

[58] Aiyub, D. Suryadi, S. Fatimah, and Kusnandi, "Investigation of Watson-Glaser critical thinking skills of junior high school students in solving mathematical problems," Journal of Physics: Conference Series, vol. 1806, no. 1, Article ID 012090, 2021.

[59] S. Desi Ratna and Caswita, "The analysis of mathematical critical thinking skills of students in junior high school," in Proceedings of the 2020 International Conference on Progressive Education (ICOPE 2019), Atlantis Press, Bandar Lampung, Indonesia, 2020. 